\title{
An Underexplored Diversity in "Yoksik Peron" [Lablab Purpureus (L.) Sweet] in East Siang, Arunachal Pradesh, India
}

DILEEP PANDEY ( $\nabla$ dkpextension@gmail.com )

Central Agricultural University https://orcid.org/0000-0003-2393-4829

\section{P. Adhiguru}

ICAR: Indian Council of Agricultural Research

Anjula Pandey

NBPGR: National Bureau of Plant Genetic Resources

P. K. Singh

Indian Agricultural Research Institute

\section{Research Article}

Keywords: Climate change, hyacinth bean, mainstreaming, morphological diversity, nutrition-sensitive agriculture.

Posted Date: August 9th, 2021

DOI: https://doi.org/10.21203/rs.3.rs-713936/v1

License: (c) (i) This work is licensed under a Creative Commons Attribution 4.0 International License. Read Full License 


\section{Abstract}

As a legume and a source of protein, hyacinth bean [Lablab purpureus (L.) Sweet] serves as a resilient and efficient source not only of calories but also of proteins and has several therapeutic properties besides, which makes it a truly multifunctional legume. The present study describes the wide morphological diversity in "Yoksik peron" (local name of lablab bean) found in Pasighat (East Siang district, Arunachal Pradesh) represented by 14 landraces conserved and cultivated by the indigenous people mainly in their backyards and kitchen gardens. The width of the pod ranged from $1.6 \mathrm{~cm}$ to $4.1 \mathrm{~cm}$ and its length, from $4.7 \mathrm{~cm}$ to $20.1 \mathrm{~cm}$. The pods also differed in colour, seed size, and shape. Many of those landraces are more resistant to several biotic and abiotic sources of stress. Such diversity offers the opportunity to identify and select the genotypes with greater tolerance to stress, thereby contributing to making the ecosystem more resilient. In addition, contemporary studies on hyacinth bean have shown the wide range of health benefits it offers, especially its potent anti-obesity properties. To realize the bean's full potential, we need an enabling policy environment for furthering research and mainstreaming to other locations.

\section{Introduction}

Hyacinth bean otherwise called lablab bean [Lablab purpureus (L.) Sweet] (Syn. Dolichos lablab) is a Leguminous crop, which is a monotypic genus belonging to the family of Leguminosae (Fabaceae) and other crops like common bean, soybean, and the garden pea (Pisum satvium L.) also belong to this family. The lablab bean is considered one of the ancient cultivated plants because of the fact the Sanganakallu excavation dating back to $1800 \mathrm{BC}$ and other several excavations in India have recorded the remains of Lablab bean (Fuller 2003). Further, there are ancient evidences to prove that lablab bean might have originated in India (Nene, 2006). For instance, testimonies of growing of lablab bean historically in India can be reasonably established from the archaeobotanical documents which points to as early as the earliest Iron Age site in Karnataka i.e. from 2000 to 1700 BC at Hallur, and also from 1200 - 300 BC at the Veerapuram excavation site in Andhra Pradesh (Fuller, 2003). By and large, Lablab purpureus is a self-fertilizing crop which is predominantly being farmed locally and is one of the underutilized crops, and mostly found in continents viz Asia, Africa and Australia (Maass et al. 2010). Based on ancient remains in India, it is supposed that from India, the lablab bean might have been introduced into Egypt, China and Western Asia (Ayyangar and Nambiar,1935). In India's neighboring country Bangladesh, in central and south-western parts of the country, it is ranked as third in terms of most important vegetable (Rashid et al. 2007).

As a legume, hyacinth bean offers a resilient and efficient source not only of calories but also of proteins and has several therapeutic properties which makes it a truly multifunctional legume (Devaraj 2016; Habib et al. 2017). This herbaceous vine shows vigorous vertical growth by means of twining around any available support. The vine locates a source of support by continually nutating (Latin nutare, 'to nod') its tip; once the tip touches a support, the vine begins to twine around the support, forming a spiral (Goriely and Neukirch 2006). Among legumes, lablab shows greater tolerance to drought, and even among 
different lines of the same species, the level of tolerance to drought varies a great deal (Ewansiha and Singh 2006; Murphy and Colucci 1999). In areas where the average annual rainfall is decreasing steadily, there is adverse effect on yields of conventional crops, which is why it is becoming increasingly important to look for alternative species of edible plants and for genotypes of existing species better suited to sparse rainfall (Guretzki and Papenbrock 2013).

However, the lablab bean remains an underexplored legume in terms of its genetics and utilization despite its wide diversity and multiple uses (Kimani et al. 2012). Although, exploration on the diversity of underutilized Lablab legume is of paramount importance to setup nutritional and economic database of the crop (Minde et al. 2020). Globally it is cultivated in different parts of the world, but in India this is highly region specific crop, especially the seed type. Given the renewed emphasis in research and development of pulses and legumes, which are now considered climate-smart crops (Kumar et al. 2019), the present study seeks to document the landraces of hyacinth bean from East Siang district of Arunachal Pradesh and to review the bean's potential as a source of protein in other parts of the country and its test its adaptability in the context of climate change.

\section{Materials And Methods}

East Siang district of Arunachal Pradesh is part of one of the world's biodiversity hot spots. Using snowball sampling, which involves tapping local networks, 43 respondents were selected, all of them being tribal farm women who regularly sell their surplus agricultural produce in the local market in Pasighat town (Fig. 1). The respondents also served as key informants and supplied details of the location of others who also cultivate "Yoksik peron" (local name of lablab bean). This information was collected from December 2019 to January 2020, that being the peak season for harvesting the "Yoksik peron". We then collected distinct landraces from the fields of those growers. Indeed, studies on plant diversity are best done through the participatory research to capture the perceptions of the local people. As a protocol, we also discussed with growers the free prior informed consent (FPIC) agreement and obtained their verbal consent for participating in the study and for allowing the data and samples collected from them to be used for the study. For revalidating the landraces of "Yoksik peron", we consulted plant breeders and other scientists from the vegetable sciences department of the College of Horticulture and Forestry, Pasighat.

\section{Results And Discussion}

Broadening the genetic base through enhancing the diversity of cultivars is the key to sustainable production of the lablab bean (Vaijayanthi and Ramesh 2019). Recognizing it, the present study documents hitherto undescribed and unreported landraces of the lablab bean. 
Table 1

Morphological characteristics of pods of different landraces of the lablab bean (Lablab purpureus)

\begin{tabular}{|c|c|c|c|c|c|c|}
\hline \multirow[t]{2}{*}{ Land-race } & \multicolumn{2}{|c|}{ Pod length } & \multicolumn{2}{|c|}{ Pod width } & \multirow{2}{*}{$\begin{array}{l}\text { No. of seeds } \\
\text { per pod }\end{array}$} & \multirow[t]{2}{*}{ Pod colour } \\
\hline & $\begin{array}{l}\text { Mean } \\
\text { (cm) }\end{array}$ & $\begin{array}{l}\text { Standard } \\
\text { deviation }\end{array}$ & $\begin{array}{l}\text { Mean } \\
\text { (cm) }\end{array}$ & $\begin{array}{l}\text { Standard } \\
\text { deviation }\end{array}$ & & \\
\hline DKP1 & 8.08 & 0.55 & 1.96 & 0.09 & 5 & Tea green \\
\hline DKP2 & 12.38 & 0.44 & 2.06 & 0.18 & 6 & Purple \\
\hline DKP3 & 20.10 & 1.26 & 2.02 & 0.16 & 6 & Forest green \\
\hline DKP4 & 16.94 & 1.19 & 4.12 & 0.54 & 7 & Kelly green \\
\hline DKP5 & 4.66 & 0.18 & 1.78 & 0.04 & 4 & Green \\
\hline DKP6 & 13.64 & 1.54 & 2.04 & 0.09 & 5 & Light green \\
\hline DKP7 & 7.28 & 0.32 & 1.76 & 0.11 & 4 & Purple \\
\hline DKP8 & 12.94 & 0.98 & 2.34 & 0.28 & 6 & Light green \\
\hline DKP9 & 15.74 & 1.18 & 2.00 & 0.14 & 6 & Banana yellow \\
\hline DKP10 & 11.42 & 0.37 & 2.62 & 0.26 & 6 & Light purple \\
\hline DKP11 & 4.98 & 0.60 & 1.56 & 0.23 & 3 & Green \\
\hline DKP12 & 13.84 & 1.05 & 2.20 & 0.20 & 5 & Light green \\
\hline DKP13 & 7.36 & 0.59 & 2.62 & 0.30 & 4 & Light purple \\
\hline DKP14 & 10.22 & 1.04 & 2.42 & 0.19 & 6 & Green \\
\hline
\end{tabular}

The indigenous people of East Siang have carefully maintained varieties of Yoksik peron, which is extensively consumed locally. Based on the present survey, which also compiled information on its cultivation and usage, 14 types of the Yoksik peron were documented. These differed in many parameters; for example, the width of the pod ranged from $1.6 \mathrm{~cm}$ to $4.1 \mathrm{~cm}$ and its length, from $4.7 \mathrm{~cm}$ to $20.1 \mathrm{~cm}$ (Table 1); the pods also differed in colour, seed size, and shape. Of the types, Nos. DKP1, DKP 4, and DKP 6 (Fig. 2) were found in abundance and also fetched higher prices than other types in the local market of Pasighat. The indigenous people consume boiled tender podsor use the bean seeds in curries or cook the pods with fish as a side dish. Thus, in this area, the Yoksik peron is in greater demand as a pod, for use as a vegetable, than as seed, unlike in southern India, where both the forms are used. Further, it was clear from information gathered from local vendors and based on our field observations that most of the Yoksik peron in East Siang were climbers, grown mainly in the backyard or in kitchen gardens and not on a commercial scale, which indicates that these are of the indeterminate type. Seeds for the next season are traditionally harvested on new moon days, locally referred to as Amavasya, which is believed 
to protect the stored seed from pests and also to prolong seed viability. Indeed, elderly women of Adi tribe are considered to be "living encyclopedias" in biocultural knowledge systems. These women play a pivotal role in retaining and transmitting on biodiversity-related traditional knowledge to the next generations (Singh et al., 2013). The knowledge and practice of elderly women about habitats and multistorey vegetations, multiplication methods, selective harvesting, and cultivation practices contribute significantly to food and livelihood security while sustaining an array of threatened plant species. The conservation of biodiversity including Yoksik peron occurs in three different habitats: jhum lands (shifting cultivation), Morang forest (community managed forests), and home gardens (Singh et al., 2013). 
Table 2

Nutritional value of the lablab bean (Lablab purpureus) per $100 \mathrm{~g}$ of raw, mature seeds

\begin{tabular}{|c|c|c|}
\hline Constituent & Nutrient value & $\begin{array}{l}\text { Percentage of } \\
\text { RDA }^{a}\end{array}$ \\
\hline Energy & $344 \mathrm{kcal}$ & $17 \%$ \\
\hline Carbohydrates & $60.74 \mathrm{~g}$ & $47 \%$ \\
\hline Protein & $23.90 \mathrm{~g}$ & $43 \%$ \\
\hline Total fat & $1.69 \mathrm{~g}$ & $8.5 \%$ \\
\hline Cholesterol & $0 \mathrm{mg}$ & $0 \%$ \\
\hline Dietary fibre & $25.6 \mathrm{~g}$ & $67 \%$ \\
\hline \multicolumn{3}{|l|}{ Vitamins } \\
\hline Folates & $23 \mu \mathrm{g}$ & $6 \%$ \\
\hline Niacin & $1.610 \mathrm{mg}$ & $10 \%$ \\
\hline Pyridoxine & $0.155 \mathrm{mg}$ & $12 \%$ \\
\hline Riboflavin & $0.136 \mathrm{mg}$ & $10 \%$ \\
\hline Thiamin & $1.130 \mathrm{mg}$ & $94 \%$ \\
\hline Vitamin A & $0 \mathrm{IU}$ & $0 \%$ \\
\hline \multicolumn{3}{|l|}{ Electrolytes } \\
\hline Sodium & $21 \mathrm{mg}$ & $1.5 \%$ \\
\hline Potassium & $1235 \mathrm{mg}$ & $26 \%$ \\
\hline \multicolumn{3}{|l|}{ Minerals } \\
\hline Calcium & $130 \mathrm{mg}$ & $13 \%$ \\
\hline Copper & $1.335 \mathrm{mg}$ & $148 \%$ \\
\hline Iron & $5.10 \mathrm{mg}$ & $64 \%$ \\
\hline Magnesium & $283 \mathrm{mg}$ & $71 \%$ \\
\hline Manganese & $1.573 \mathrm{mg}$ & $68 \%$ \\
\hline Phosphorus & $0.372 \mathrm{mg}$ & $53 \%$ \\
\hline Selenium & $8.2 \mu \mathrm{g}$ & $15 \%$ \\
\hline
\end{tabular}

${ }^{a}$ recommended dietary allowance 


\begin{tabular}{|lll|}
\hline Constituent & Nutrient value & $\begin{array}{l}\text { Percentage of } \\
\text { RDA }^{a}\end{array}$ \\
\hline Zinc & $9.30 \mathrm{mg}$ & $84 \%$ \\
\hline a ${ }^{\text {a recommended dietary allowance }}$ \\
\hline
\end{tabular}

Source: USDA National Nutrient database; https://www.nutrition-and-you.com/hyacinth-bean.html

Apart from the nutritional value of the bean (Table 2), a scooping review (Al-Snafi 2017) describes its value in pharmacology and its medicinal importance. Recent studies on the nutraceutical properties of the lablab bean confirm its value as a functional food, which could be used for the treatment of obesity and related diseases (Suh et al. 2017; Vidigal et al. 2018; Yin et al. 2018). Thus, apart from its nutty creamy taste, the bean, not only a source of calories and of proteins but also has other health benefits. The lablab bean, given its prolific yield, versatility, and adaptability to adverse and harsh conditions is undeniably one of the legumes for the future. Because of its phenomenal resilience to drought and salinity, it is also suitable for field production (Murphy and Colucci 1999; Jaleel. et al. 2009; D'Souza and Devaraj 2010; Devaraj and D'Souza 2016). The bean is well adapted to dry environments and copes with droughts by minimizing the loss of water by maintaining the right balance between vegetative and reproductive growth (Sennhenn et al. 2017; Naeem et al. 2020).

\section{Market Potential}

Although primarily cultivated for household consumption, of late, in villages like Balek, Bodak, Mirem, Rani, Ruksin and Taki Lalung, local people ventured its mass cultivation, after realizing its huge market demand. Like most of the less known crops and wild plants/ vegetables were sold in regular market of " Pasighat" and "Ruksin" local markets directly by farmers (Fig. 1) as well as by a few permanent retailers in commercial markets. Interviews with the sellers/retailers revealed almost a threefold increase in price from 2017-18. The market rates for the pods/ seeds was INR 150-200/Kg. in market of Pasighat town, Arunachal Pradesh while, fresh pod sold at $50-75 / \mathrm{Kg}$. The local types Yoksik peron with green colored pods were commonly available and fetched better price as compared to others. On an average, a farmer growing ten clumps in backyards earns INR 5000 per annum.

\section{Conclusion}

The lablab bean has hitherto been only of regional significance because of its restricted cultivation and its limited popularity; it has remained localized and has not been subjected to sufficient selection pressure. Furthermore, the study uncovers diversity with nutritional and medicinal values may pick interest of market value for underutilized Yoksik peron as a commercial product and this is vital to famer's economic advantages. The literature briefly reviewed here shows its nutritional and pharmacological properties and its ability to adapt to abiotic and biotic forms of stress-that are likely to 
become even more severe as a result of climate change. Despite these considerable merits, the Yoksik peron has received little attention from researchers and conservationists, and the current agricultural statistics ignore its production. It is therefore necessary to formulate conducive policies and garner institutional support for research on the effective utilization of the many and diverse landraces of the Yoksik peron, which will be a valuable addition to mainstream diets.

\section{Declarations}

Acknowledgements Authors express their sincere thanks to the Indigenous people of East Siang, Arunachal Pradesh for their help rendered during the study. Thanks to the Dean, College of Horticulture \& Forestry, Central Agricultural University, Pasighat, Arunachal Pradesh for extending technical support.

\section{Compliance with ethical standards}

Conflict of interest Authors declare that they have no conflict of interest on the content of the manuscript and study undertaken.

\section{References}

1. Al-Snafi AE (2017) The pharmacology and medical importance of Dolichos lablab (Lablab purpureus)-A review. IOSR J Pharm 7(2):22-30

2. Ayyangar GR, Nambiar KKK (1935) Studies in Dolichos lablab (Roxb.) and (L.)-The Indian field and garden bean. 1. In Proceedings of the Indian Academy of Sciences-Section B, Springer India, 1(12) pp. 857-867

3. D'Souza MR, Devaraj VR (2010) Biochemical responses of Hyacinth bean (Lablab purpureus) to salinity stress. Acta Physiol Plant 32(2):341-353

4. Devaraj VR, D'Souza MR (2016) Hyacinth bean (Lablab purpureus): an adept adaptor to adverse environments. in: special issue on hyacinth bean: a gem among legumes. Legume Perspect 13:2022

5. Devaraj VR (2016) Economic importance of hyacinth bean (Lablab purpureus L.): An Indian perspective. Special Issue on Hyacinth Bean: A gem Among Legumes. Legume Perspect 13:37-38

6. Ewansiha SU, Singh BB (2006) Relative drought tolerance of important herbaceous legumes and cereals in the moist and semi-arid regions of West Africa. J Food Agric Environ 4(2):188-190

7. Fuller Dorian Q (2003) African crops in prehistoric South Asia: a critical review. Food, fuel and fields: Progress in African archaeobotany, 239-271

8. Goriely A, Neukirch S (2006) Mechanics of climbing and attachment in twining plants. Phys Rev Lett 97(18):184302

9. Guretzki S, Papenbrock J (2013) Comparative analysis of methods analyzing effects of drought on the herbaceous plant Lablab purpureas. J Appl Bot Food Qual 86(1):47-54 
10. Habib HM, Theuri SW, Kheadra EE, Mohamed FE (2017) Functional, bioactive, biochemical, and physicochemical properties of the Dolichos lablab bean. Food Funct 8:872-880

11. Jaleel CA, Manivannan PA, Wahid A, Farooq M, Al-Juburi HJ, Somasundaram RA, Panneerselvam R (2009) Drought stress in plants: a review on morphological characteristics and pigments composition. Int J Agric Biol Eng 11:100-105

12. Kimani E, Wachira F, Kinyua M (2012) Molecular diversity of Kenyan lablab bean (Lablab purpureus (L.) Sweet) Lablab purpureus related to provenance of germplasm by using amplified fragment length polymorphism. Genet Resour Crop Evol 52:683-695

13. Kumar J, Choudhary AK, Gupta DS, Kumar S (2019) Towards exploitation of adaptive traits for climate-resilient smart pulses. Int J Mol Sci 20(12):2971

14. Maass B, Knox M, Venkatesha S, Angessa T, Ramme S, Pengelly B (2010) Lablab purpureus -a crop lost for Africa? Trop Plant Biol 3:123-135

15. Minde JJ, Venkataramana PB, Matemu AO (2020) Dolichos Lablab-an underutilized crop with future potentials for food and nutrition security: a review. Crit Rev Food Sci Nutr, 1-13

16. Murphy AM, Colucci PE (1999) A tropical forage solution to poor quality ruminant diets: a review of Lablab purpureus. Livestock Research for Rural Development (FAO) 11:96-113

17. Naeem M, Shabbir A, Ansari AA, Aftab T, Khan MMA, Uddin M (2020) Hyacinth bean (Lablab purpureus L.)-An underutilised crop with future potential. Sci Hortic 272:109551

18. Nene YL (2006) Indian pulses through the millennia. Asian Agri-History 10(3):179-202

19. Rashid MA, Tauhidur Rahman M, Shahadad Hussain M, Motiur Rahaman M (2007) Indigenous Vegetables in Bangladesh. Acta Hortic 752:397-400

20. Sennhenn A, Njarui DM, Maass BL, Whitbread AM (2017) Exploring niches for short-season grain legumes in semi-arid Eastern Kenya-coping with the impacts of climate variability. Front Plant Sci 8:699

21. Singh RK, Rallen O, Padung E (2013) Elderly Adi Women of Arunachal Pradesh:“Living encyclopedias" and cultural refugia in biodiversity conservation of the Eastern Himalaya, India. Environ Manage 52(3):712-735

22. Suh $\mathrm{DH}$, Lee HW, Jung ES, Singh $\mathrm{D}, \mathrm{Kim} \mathrm{SH}$, Lee $\mathrm{CH}$ (2017) In vivo metabolomic interpretation of the anti-obesity effects of hyacinth bean (Dolichos lablab L.) administration in high-fat diet mice. Mol Nutr Food Res 61(8):1600895

23. Vaijayanthi PV, Ramesh S (2019) Hyacinth Bean (Lablab purpureus L. Sweet): Genetics, Breeding and Genomics. In: Advances in Plant Breeding Strategies: Legumes. Springer, Cham, pp 287-318

24. Vidigal P, Duarte B, Cavaco AR, Caçador I, Figueiredo A, Matos AR, Viegas W, Monteiro F (2018) Preliminary diversity assessment of an undervalued tropical bean (Lablab purpureus (L.) Sweet) through fatty acid profiling. Plant Physiol Bioch 132:508-514

25. Yin J, Seo CS, Hwang IH, Lee MW, Song KH (2018) Anti-obesity activities of chikusetsusaponinIVa and Dolichos lablab L. seeds. Nutrients 10(9):1221 


\section{Figures}

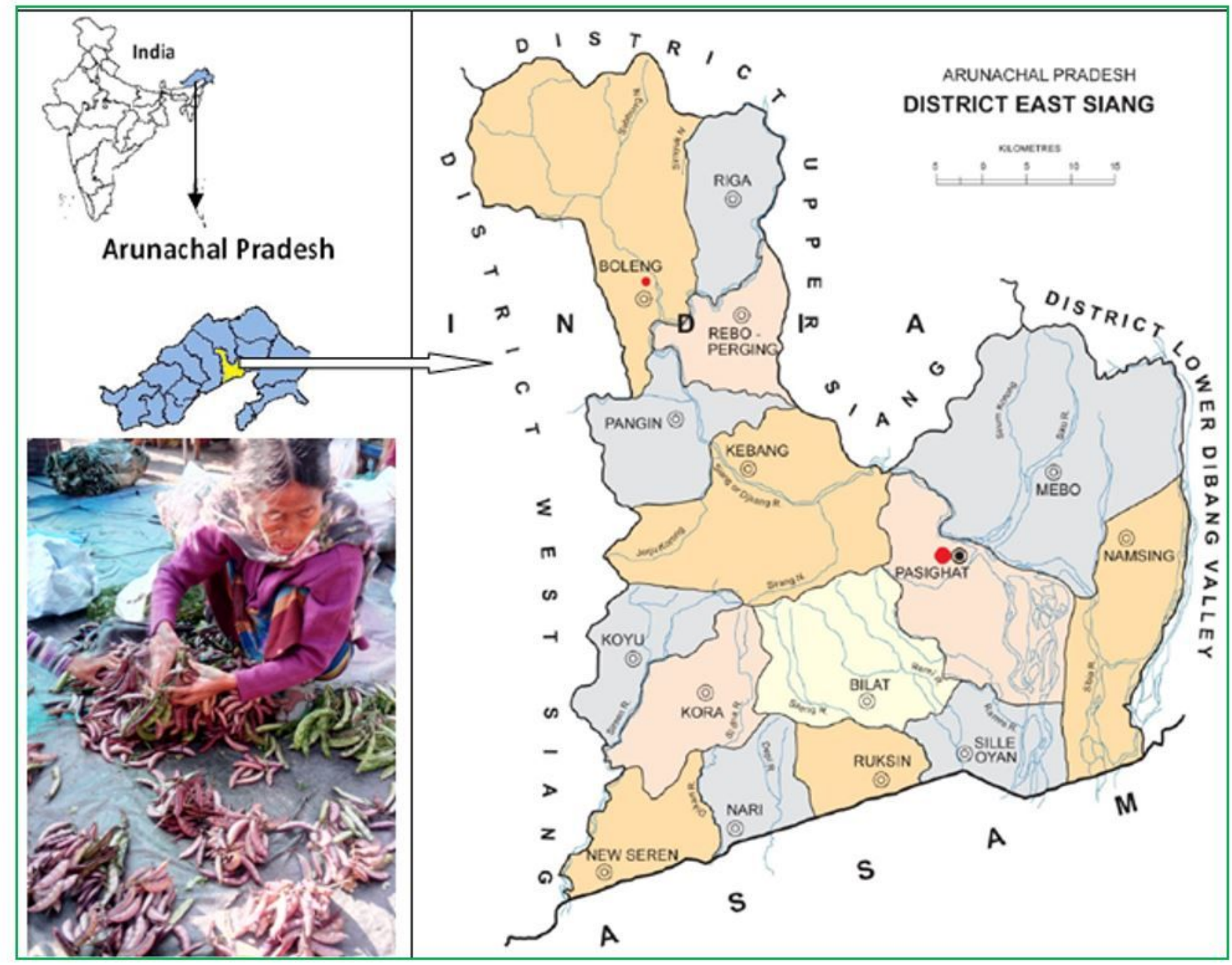

Figure 1

Study area: Pasighat, East Siang district, Arunachal Pradesh. 


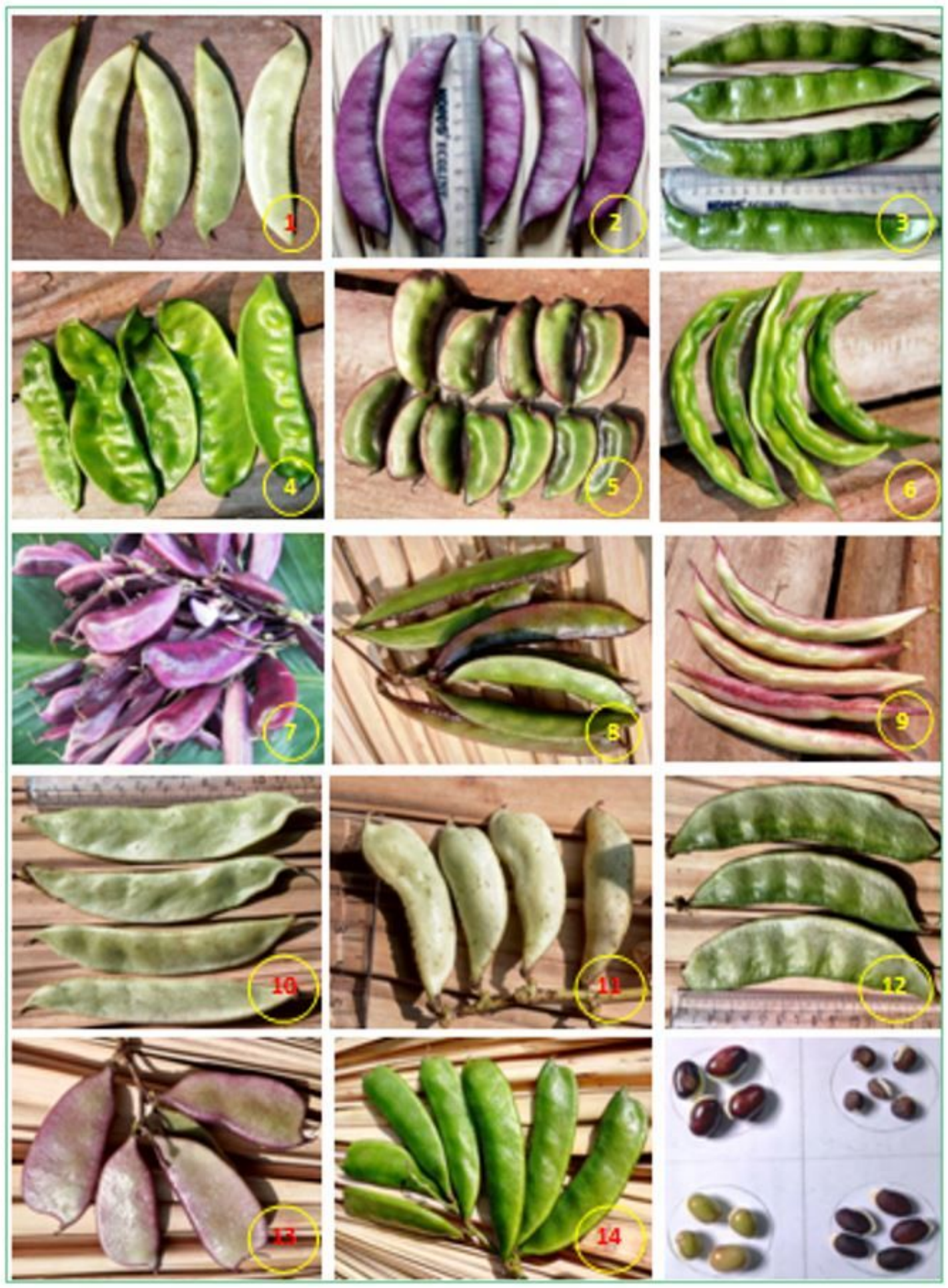

\section{Figure 2}

Diversity of landraces of the lablab bean (Lablab purpureus) collected from East Siang district, Arunachal Pradesh. 